\title{
Removal of a suture needle: a case report
}

Suyun Seon, Baek-Soo Lee, Byung-Joon Choi, Joo-Young Ohe, Jung-Woo Lee, Junho Jung, Bo-Yeon Hwang, Min-Ah Kim and Yong-Dae Kwon* (1)

\begin{abstract}
Background: Foreign bodies may be embedded or left behind in the oral cavity during oral surgical procedure. The loss of instruments such as impression material, surgical gauze, and broken injection needles are commonly reported in the dental field. These complications are generally symptomatic and show signs of inflammation, pain, and purulent discharge. Accidental breakage of suture needles is a rare but potentially dangerous event.

Case presentation: In this report, we present one case of lost suture needle during the procedure of flap operation at local dental clinic and its successful removal under local/general anesthesia administration via CBCT with a help of two reference needles to localize the 6-0 nylon needle and consulting with the clinician.

Conclusion: $C T$ scanning taken while mouth-closing may not be accurate with regard to real location measurement performed while mouth-opening. If so, other up-to-date radiographic devices and methods to retrieve a needle are recommended.
\end{abstract}

Keywords: Needle fracture, Suture needle, latrogenic foreign body, Foreign body removal, Oral cavity

\section{Background}

Various suture materials are used in the intraoral surgery and frequently penetrate the soft tissue of the oral cavity. This surgery is usually associated with implant surgery, dental surgical extraction, periodontal flap surgery, oral-maxillofacial surgery including bone grafts, osteomyelitis, cancer operation, and operative trauma. Due to many factors such as limited intraoperative visibility and difficult access, sudden movement of patients, the size of the instruments, and mishandling of surgeons with lack of experiences, the materials and instruments used in oral surgery can be broken, displaced, embedded, and left behind during these surgeries. Patients with this condition often experience unpleasant symptoms such as pain in operation site, post-operative exudate, and swelling, and some of these foreign bodies that are adjacent to the vital anatomical structures can lead to serious complications such as massive bleeding, nerve injuries, and purulent inflammation leading to airway

\footnotetext{
* Correspondence: kwony@khu.ac.kr

Department of Oral and Maxillofacial surgery, School of Dentistry, Kyung Hee University, 26, Kyungheedae-ro, Dongdaemun-gu, Seoul 130-701, South
} Korea

obstruction and suffocation. There are various ways recommended for the treatment of retained foreign body removal in the literatures. The key to removing foreign bodies in head and neck surgery is exact localization and surgical approaches. We report one successful case of removing the suture needle that is used in a flap surgery for bone graft with an assistance of CT image and two injection needles inserted as reference points to exactly localize and detect.

\section{Case presentation} ment to refred by his dental clinician to our departmucosa. The patient had undergone explantation surgery with bone grafts on the \#26i, 27i due to the chronic peri-implantitis in the local clinic. The procedure was accompanied by local flap surgery to cover the grafted bone material filling the extracted area for better bone formation and healing. The sutures were supposed to be tied with 6-0 nylon, but the suture needle was cut off during the procedure. Although the local clinic 


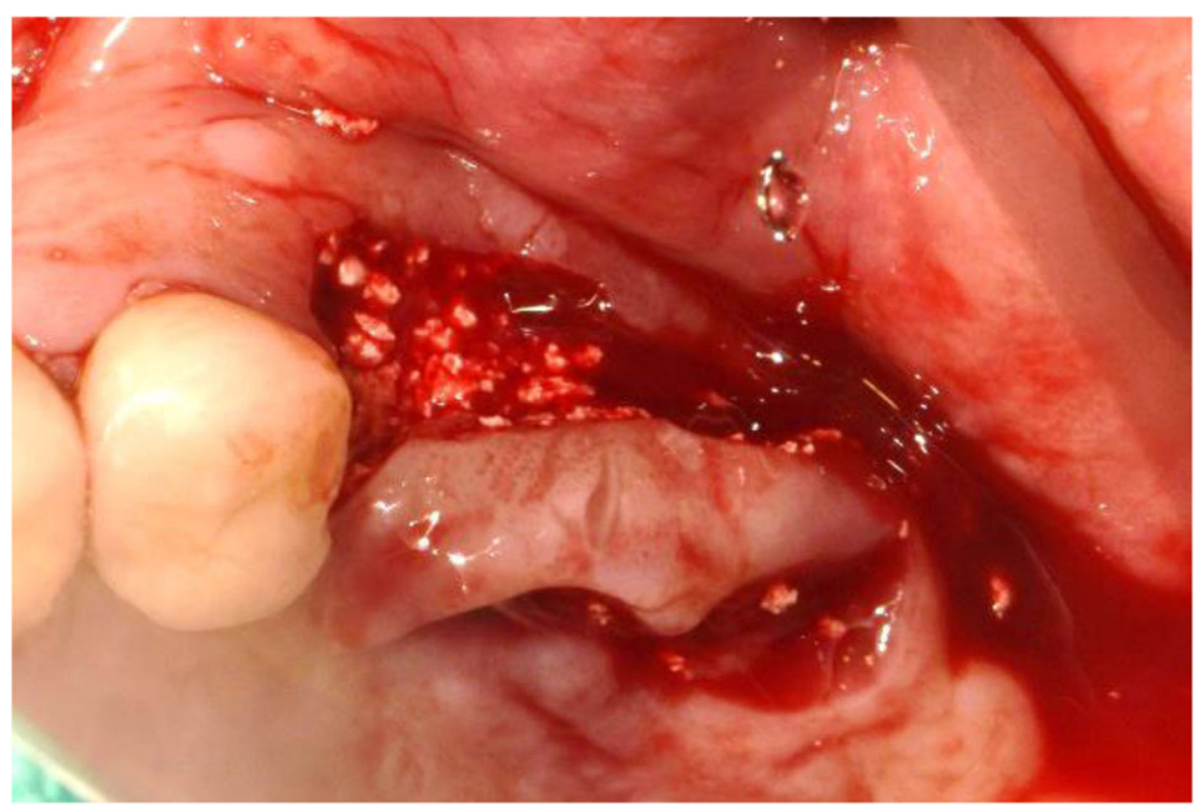

Fig. 1 Clinical photo taken right after flap operation of explantation at the local dental clinic

immediately attempted to retrieve the suture needle using additional panorama and CT, their attempt failed (Fig. 1).

Upon his arrival to our department without bringing any radiographs, the patient was complaining of sharp pain on the operation site with no limitation in his ability to open his mouth. Panoramic radiograph confirmed that the suture needle still stayed in the left buccal space, anterior to the ramus of mandible (Fig. 2A). The oral examination with palpation was performed, and two injection needles were inserted almost perpendicular to each other into the left buccal mucosa near the anterior border of mandibular ramus in order to locate the needle as reference points. Cone beam computed tomography was performed and revealed that the broken needle was located above the injection needle and below the maxillary tuberosity (Fig. 2B).
It was decided that surgical exploration under local anesthesia was the most appropriate way to remove the broken needle. A vertical incision on the left buccal mucosa along the ramus was made, and the blunt dissection using a dissecting scissor was performed. The needle, however, was invisible, and the first attempt failed due to the patient's pain.

Following discussion with patient and patient's caregiver about the possible risks of migrating the needle into deeper layers and damaging anatomical vital structures with the further exploration under local anesthesia, they agreed to the retrieval of the suture needle under general anesthesia.

On the following day, the patient underwent the surgical exploration under general anesthesia. Taking the clinician's information that the initial suture was performed on the left upper second molar region into
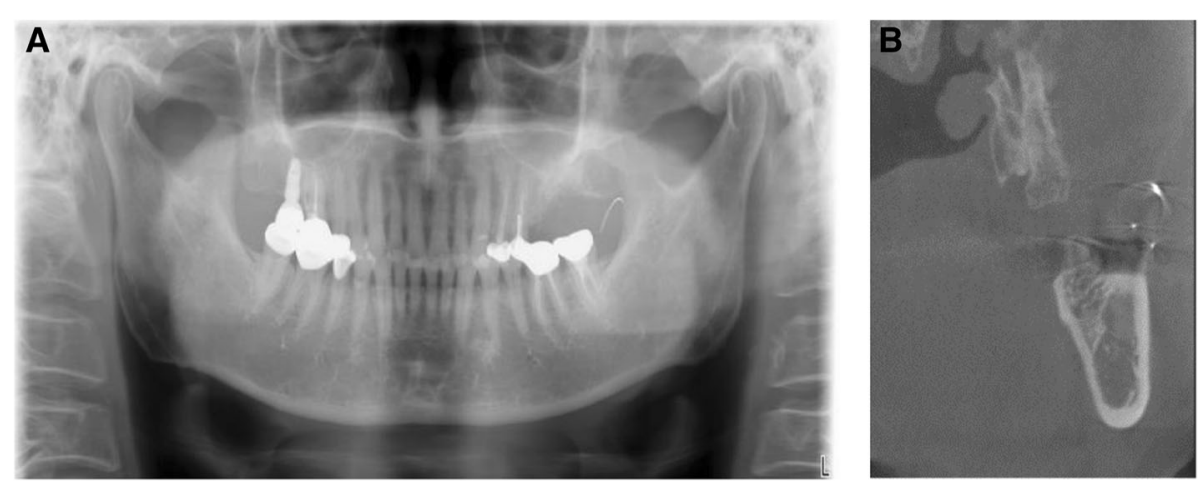

Fig. 2 A Panoramic radiograph taken on arrival shows needle fragment located at the anterior ramus of left mandible. B CBCT image of the lost needle with 2 injection needles as reference points 
consideration, the additional vertical incision was made on the left buccal mucosa at the height level of upper occlusal plane. Careful exploration began by blunt dissection with curved and straight mosquitoes to expose the deep soft tissue layers. Further exploration was performed, and the broken 6-0 nylon round needle was identified in one piece (Fig. 3A). The needle was approximately $1.3 \mathrm{~cm}$ long, and the nylon fragment was attached to it (Fig. 3B). After the retrieval of the needle, the mucosal incision was closed up using 4-0 Vicryl. Post-operative radiographs were taken afterwards and confirmed that the broken needle was successfully removed. 1 week later, the stitches were removed, and the patient had progression of healing on the surgical site without any infection or complication.

\section{Discussion}

The loss of surgical needles is estimated to be a quite common occurrence during a surgical procedure especially in the surgical departments of the medical field, while reports in the dental field for a loss of needles are relatively scarce. Jayadevan et al. [1] reported $65 \%$ of medical surgeons in their survey conducted in 2014 experienced lost surgical needles in the USA and designed a protocol to recover the lost needle during minimally invasive surgery.

Previous studies have reported accidental injection needle fractures and successful retrieval. However, suture needle events tend to be rare and less reported in the oral surgical field (Table 1). Blum et al. [32] reported 100 cases of needle breakage occurred from 1914 to 1928 and Catelani et al. [18] reported 82 cases of broken anesthetic needles since 1965. Augello et al. [33] reviewed the literature of the last 50 years and reported
70 percent of needle breakage events occurred with inferior alveolar nerve block anesthesia in the pterygomandibular space. Although the incidence of needle fracture has decreased due to the introduction of stainless and flexible metal alloys, many cases of needle fracture have been constantly reported without any consensus on methods to retrieve the needle fragments or the guidelines on how to remove the lost needle.

Archer et al. [34] and Kennett et al. [35] reported management of broken needles using radiographs such as lateral and posterior-anterior views to locate the broken needles. As the panoramic radiograph has improved, preoperative diagnosis has become accurate and the surgical success has increased. Since the early 2000s, many authors reported the use of computed tomography for removal of the needles, and three-dimensional imaging techniques (CBCT) have become standard for localization and treatment strategies with the advantage of visualizing not only foreign bodies but also surrounding anatomical structures $[4,20,24,29]$. Other techniques like fluoroscopy and mobile digital $\mathrm{C}$-arm were introduced and suggested as reliable radiographic tools for needle retrieval $[8,13]$. Keeping up with the latest technology, recent radiographic development illuminates the surgical navigation system to be the sophisticated tracking equipment as described by Lee and Zaid [27], Gerbino et al. [19], and Stein [29].

Many reports have described and/or recommended the use of reference needles placed in situ with additional radiographic images taken repeatedly for an effective localization of the needle $[5,8,9,11,15,16,18$, 24, 36-38]. Thompson et al. [5] reported that the use of two venipuncture needles can be successfully applied as reference needles.
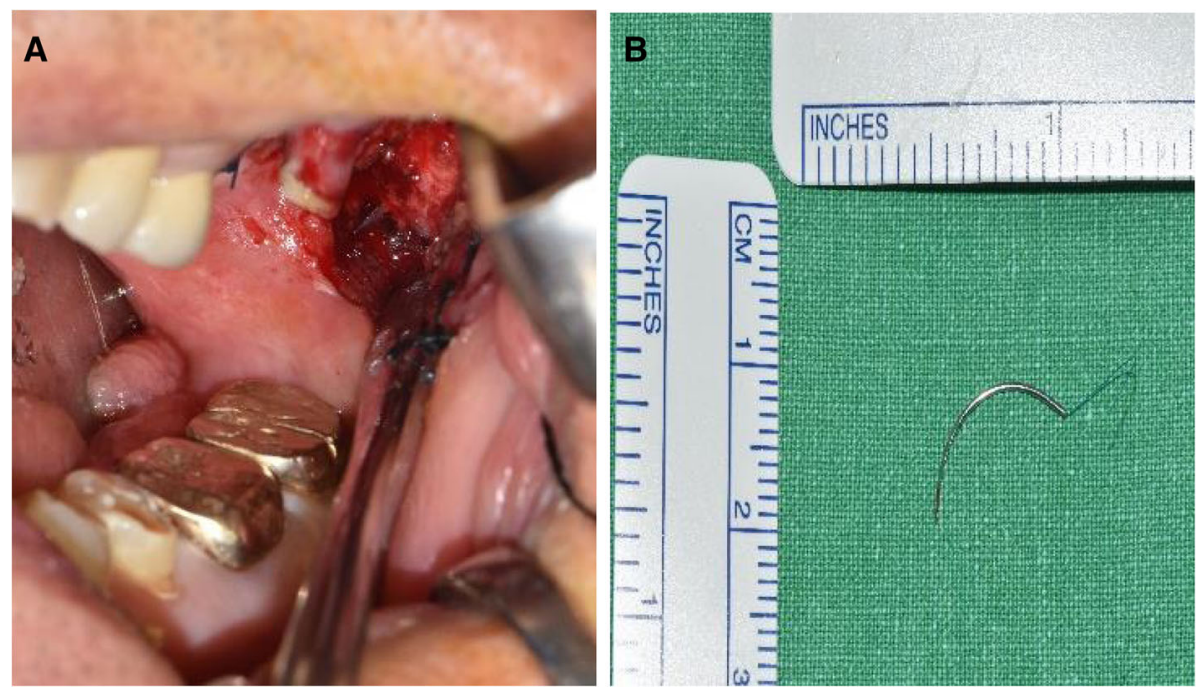

Fig. 3 A A single needle fragment embedded in the buccal mucosa. B The suture needle successfully retrieved 
Table 1 Recent cases of needle removal

\begin{tabular}{|c|c|c|c|c|c|c|}
\hline $\begin{array}{l}\text { Authors } \\
\text { (year) }\end{array}$ & $\begin{array}{l}\text { Type of } \\
\text { needle }\end{array}$ & cases & Site of needle fragment & Detection method & $\begin{array}{l}\text { Required } \\
\text { time }\end{array}$ & $\begin{array}{l}\text { Successful } \\
\text { removal }\end{array}$ \\
\hline $\begin{array}{l}\text { McDonogh } \\
\text { (1996) [2] }\end{array}$ & $\begin{array}{l}\text { Injection } \\
\text { needle }\end{array}$ & 1 & Retromolar region (right) & $\begin{array}{l}\text { DPR, oblique lateral, lateral skull. RG } \\
\text { KEELER metal detector }\end{array}$ & $1 \mathrm{~h}$ & Yes \\
\hline $\begin{array}{l}\text { Bhatia } \\
\text { (1998) [3] }\end{array}$ & $\begin{array}{l}\text { Injection } \\
\text { needle }\end{array}$ & 1 & Pterygo-mandibular space (left) & PA RG & $2 \mathrm{~h}$ & Yes \\
\hline $\begin{array}{l}\text { Zeltser } \\
\text { (2002) [4] }\end{array}$ & $\begin{array}{l}\text { Injection } \\
\text { needle }\end{array}$ & 1 & Pterygo-mandibular space (left) & $\begin{array}{l}\text { DPR, PA RG, CT, } 23 G \text { needle soaked in } \\
\text { methylene blue }\end{array}$ & Immediately & Yes \\
\hline $\begin{array}{l}\text { Thompson } \\
\text { (2003) [5] }\end{array}$ & $\begin{array}{l}\text { Injection } \\
\text { needle }\end{array}$ & 2 & Pterygo-mandibular space (right, left) & $\begin{array}{l}\text { RG, image intensifier with } 2 \text { reference } \\
\text { needles }\end{array}$ & Immediately & Yes \\
\hline $\begin{array}{l}\text { Ethunandan } \\
\text { (2007) [6] }\end{array}$ & $\begin{array}{l}\text { Injection } \\
\text { needle }\end{array}$ & 1 & Pterygo-mandibular space (right) & $\begin{array}{l}\text { DPR, PA mandible, lateral cephalometric } \\
\text { RG, CT }\end{array}$ & 6 months & Yes \\
\hline $\begin{array}{l}\text { Dojcinovic } \\
\text { (2007) [7] }\end{array}$ & $\begin{array}{l}\text { Injection } \\
\text { needle }\end{array}$ & 1 & Pterygo-mandibular space (left) & DPR, radioscopy & Immediately & Yes \\
\hline $\begin{array}{l}\text { Nezafati } \\
\text { (2008) [8] }\end{array}$ & $\begin{array}{l}\text { Injection } \\
\text { needle }\end{array}$ & 1 & Pterygo-mandibular space (right) & CT, 18G needle, digital C-Arm & 2 days & Yes \\
\hline $\begin{array}{l}\text { Pogrel } \\
\text { (2009) [9] }\end{array}$ & $\begin{array}{l}\text { Injection } \\
\text { needle }\end{array}$ & 16 & $\begin{array}{l}\text { Medial pterygoid muscle (left) }(n=1) \text {, not } \\
\text { defined }(n=15)\end{array}$ & $\begin{array}{l}\text { DPR, CT, intra-operative RG with } 2 \\
\text { spinal needles }\end{array}$ & & Yes \\
\hline $\begin{array}{l}\text { Chrcanivic } \\
\text { (2009) [10] }\end{array}$ & $\begin{array}{l}\text { Injection } \\
\text { needle }\end{array}$ & 1 & Pterygo-mandibular space (left) & Lateral skull RG & Immediately & Yes \\
\hline $\begin{array}{l}\text { Augello } \\
\text { (2009) [11] }\end{array}$ & $\begin{array}{l}\text { Injection } \\
\text { needle }\end{array}$ & 1 & Masseter (right) & DPR, CT, fluoroscopy & Immediately & Yes \\
\hline $\begin{array}{l}\text { Hassani } \\
(2010)[12]\end{array}$ & $\begin{array}{l}\text { Suture } \\
\text { needle }\end{array}$ & 1 & Tuberosity hamular-notch region & $\mathrm{DPR}, \mathrm{CBCT}$ & 4 years & Yes \\
\hline $\begin{array}{l}\text { Sencimen } \\
(2010)[13]\end{array}$ & $\begin{array}{l}\text { Suture } \\
\text { needle }\end{array}$ & 1 & Pterygo-mandibular space (left) & $\begin{array}{l}\text { DPR, CT, C-arm fluoroscope (Philips } \\
\text { Medical Systems) }\end{array}$ & Few days & Yes \\
\hline $\begin{array}{l}\text { Prado (2010) } \\
{[14]}\end{array}$ & $\begin{array}{l}\text { Injection } \\
\text { needle }\end{array}$ & 1 & $\begin{array}{l}\text { Pterygo-mandibular space (right), migration to } \\
\text { skull base }\end{array}$ & $\mathrm{CT}$ & & No \\
\hline $\begin{array}{l}\text { Rifkind } \\
\text { (2011) [15] }\end{array}$ & $\begin{array}{l}\text { Injection } \\
\text { needle }\end{array}$ & 1 & Pterygo-mandibular space (right) & $\begin{array}{l}\text { DPR, CT, intra-operative fluoroscopy } \\
\text { with } 2 \text { reference needles }\end{array}$ & 8 days & Yes \\
\hline $\begin{array}{l}\text { Bacci (2012) } \\
{[16]}\end{array}$ & $\begin{array}{l}\text { Injection } \\
\text { needle }\end{array}$ & 1 & Anterior part of temporalis muscle & DPR, fluoroscopy & Immediately & Yes \\
\hline $\begin{array}{l}\text { Brucoli } \\
(2012)[17]\end{array}$ & $\begin{array}{l}\text { Injection } \\
\text { needle }\end{array}$ & 1 & Pterygo-mandibular space (left) & DPR, fluoroscopy & 1 month & Yes \\
\hline \multirow[t]{4}{*}{$\begin{array}{l}\text { Catelani } \\
\text { (2013) [18] }\end{array}$} & $\begin{array}{l}\text { Injection } \\
\text { needle }\end{array}$ & 4 & Pterygo-mandibular space (left) & $\begin{array}{l}\mathrm{CT} \text {, fluoroscopy (C-arm with } 2 \text { reference } \\
\text { needles, methylene technique) }\end{array}$ & Immediately & Yes \\
\hline & & & & & Immediately & Yes \\
\hline & & & Extra-corporeal & & Immediately & \\
\hline & & & Pterygo-mandibular space (right) & $\begin{array}{l}\mathrm{CT} \text {, fluoroscopy (C-arm with } 2 \text { reference } \\
\text { needles, methylene technique) }\end{array}$ & & Yes \\
\hline $\begin{array}{l}\text { Gerbino } \\
\text { (2013) [19] }\end{array}$ & $\begin{array}{l}\text { Injection } \\
\text { needle }\end{array}$ & 1 & Pterygo-mandibular space (left) & DPR, CT, navigation system (BrainLAB) & 1 day & Yes \\
\hline $\begin{array}{l}\operatorname{Kim}(2013) \\
{[20]}\end{array}$ & $\begin{array}{l}\text { Injection } \\
\text { needle }\end{array}$ & 1 & $\begin{array}{l}\text { Between coronoid process and condyle neck } \\
\text { area(left) }\end{array}$ & $\mathrm{DPR}, \mathrm{CT}$ & & Yes \\
\hline $\begin{array}{l}\text { Nicot (2013) } \\
{[21]}\end{array}$ & $\begin{array}{l}\text { Injection } \\
\text { needle }\end{array}$ & 1 & Subangulo-mandibular region & DPR, CT & 5 days & Yes \\
\hline $\begin{array}{l}\text { Rahman } \\
\text { (2013) [22] }\end{array}$ & $\begin{array}{l}\text { Injection } \\
\text { needle }\end{array}$ & 1 & $\begin{array}{l}\text { In the vicinity of the lingula (right), migration } \\
\text { to postauricular area }\end{array}$ & DPR, lateral oblique $\mathrm{RG}, \mathrm{CT}$ & 2 weeks & Yes \\
\hline $\begin{array}{l}\text { Ribeiro } \\
\text { (2014) [23] }\end{array}$ & $\begin{array}{l}\text { Injection } \\
\text { needle }\end{array}$ & 1 & $\begin{array}{l}\text { Pterygo-mandibular space (left), migration to } \\
\text { medial wall of external auditory canal }\end{array}$ & $\mathrm{CT}$ & $>12$ month & Yes \\
\hline $\begin{array}{l}\text { Acham } \\
\text { (2014) [24] }\end{array}$ & $\begin{array}{l}\text { Injection } \\
\text { needle }\end{array}$ & 1 & Mandibular notch & $\begin{array}{l}\text { DPR, CBCT, C-arm with } 2 \text { reference } \\
\text { needles }\end{array}$ & $6 \mathrm{~h}$ & Yes \\
\hline $\begin{array}{l}\text { Bailey (2015) } \\
{[25]}\end{array}$ & $\begin{array}{l}\text { Injection } \\
\text { needle }\end{array}$ & 1 & Pterygo-mandibular space (right) & DPR, PA mandibular RG & Immediately & Yes \\
\hline
\end{tabular}


Table 1 Recent cases of needle removal (Continued)

\begin{tabular}{|c|c|c|c|c|c|c|}
\hline $\begin{array}{l}\text { Authors } \\
\text { (year) }\end{array}$ & $\begin{array}{l}\text { Type of } \\
\text { needle }\end{array}$ & cases & Site of needle fragment & Detection method & $\begin{array}{l}\text { Required } \\
\text { time }\end{array}$ & $\begin{array}{l}\text { Successful } \\
\text { removal }\end{array}$ \\
\hline $\begin{array}{l}\text { Casey (2015) } \\
{[26]}\end{array}$ & $\begin{array}{l}\text { Injection } \\
\text { needle }\end{array}$ & 1 & Adjacent to the internal carotid artery & CT & 4 years & Yes \\
\hline $\begin{array}{l}\text { Lee }(2015) \\
{[27]}\end{array}$ & $\begin{array}{l}\text { Injection } \\
\text { needle }\end{array}$ & 1 & $\begin{array}{l}\text { Pterygo-mandibular space above lingula } \\
\text { (right) }\end{array}$ & $\begin{array}{l}\text { DPR, CT, navigation system (Medronci } \\
\text { AxiEM) }\end{array}$ & 1 year & Yes \\
\hline $\begin{array}{l}\text { Okumura } \\
\text { (2015) [28] }\end{array}$ & $\begin{array}{l}\text { Injection } \\
\text { needle }\end{array}$ & 1 & $\begin{array}{l}\text { Parapharyngeal space adjacent to external } \\
\text { carotid artery (right) }\end{array}$ & $\begin{array}{l}\mathrm{CT} \text {, facial x-ray, fluoroscopy, K-wire as } \\
\text { reference bar }\end{array}$ & 1 month & Yes \\
\hline $\begin{array}{l}\text { Stein }(2015) \\
{[29]}\end{array}$ & $\begin{array}{l}\text { Injection } \\
\text { needle }\end{array}$ & 1 & Pterygo-mandibular space (right) & $\begin{array}{l}\text { CBCT, navigation system (Medtronic } \\
\text { StealthStation S7) }\end{array}$ & Immediately & Yes \\
\hline $\begin{array}{l}\text { Aktop (2015) } \\
{[30]}\end{array}$ & $\begin{array}{l}\text { Suture } \\
\text { needle }\end{array}$ & 1 & Nearly below the medial pterygoid plate & DPR, CBCT & Immediately & Yes \\
\hline $\begin{array}{l}\text { Queiroz } \\
\text { (2016) [31] }\end{array}$ & $\begin{array}{l}\text { Injection } \\
\text { needle }\end{array}$ & 1 & Cervical region close to facial artery & $\mathrm{CT}, \mathrm{C}$-arm image intensifier & Few days & Yes \\
\hline
\end{tabular}

$\mathrm{DPR}, \mathrm{CT}, \mathrm{CBCT}, \mathrm{PA}$, and RG represent dental panoramic radiography, computed tomography, cone beam computed tomography, posterior-anterior, and radiography respectively

Various methods to retrieve the fragment in the maxillofacial region were attempted and described in the past literatures. Although magnet received noticeable attention when introduced by Cohen [39] in 1963, other several authors reported that the use of magnets to determine the position and remove the fragment was not an ideal option since the hypodermic needles have a weak response to magnets [6]. Then, a metal detector was tried by McDonogh [2] and Okumura et al. [28] showing successful retrieval of an embedded broken needle.

Although CBCT is considered a precise method of imaging the location of a broken object in relation to adjacent anatomical landmarks, it is difficult to correlate the actual position with CT images owing to different intraoperative head and mouth-opening position compared to the mouth-closing position of CT images. Park et al. [40] described that CT scanning may not be accurate with regard to real position due to intraoperative traction and swelling and reported that the dental mini Carm device was more beneficial in determining and confining the location of broken objects with intraoperative real time information. On this report, possible migration of the suture needle during the surgery made the situation challenging and the measurement on the CBCT scans was not helpful. Therefore, other up-to-date radiographic devices can be sometimes advisable when CT scan images are not practical. It should also be noted that surgeons sufficiently consult with the clinician who refers the patients by exchanging the information of the patient for the better diagnosis and accurately locating the lost objects in the oral cavity.

\section{Conclusion}

This study reported a rare clinical case of removing the suture needle with the help of CBCT images. CT scanning taken while mouth-closing may not be accurate with regard to real location measurement performed while mouth-opening. If so, other up-to-date radiographic devices and methods to retrieve a needle are recommended.

\section{Abbreviations}

CBCT: Cone beam computed tomography; CT: Computed tomography

\section{Acknowledgements}

Not applicable

Authors' contributions

SS and YDK have conceived and drafted the manuscript. BSL, BJC, JYO, JWL, $J H J, B Y W$, and MAK have participated in the design and coordination of this study. SS has collected the data, and YDK have revised and corrected the article. All authors read and approved the final manuscript.

\section{Funding}

Not applicable

Availability of data and materials Non applicable

\section{Declarations}

Ethics approval and consent to participate Non applicable

\section{Consent for publication}

Written informed consent has been obtained from the patient for publication of this case report and the accompanying images.

\section{Competing interests}

We have no conflicts of interest or connected interests with this work. We declare that we have no competing financial interest.

Received: 18 March 2021 Accepted: 25 June 2021

Published online: 05 July 2021

References

1. Jayadevan R, Stensland K, Small A, Hall S, Palese M (2014) A protocol to recover needles lost during minimally invasive surgery. JSLS 18. https://doi. org/10.4293/JSLS.2014.00165

2. McDonogh T (1996) An unusual case of trismus and dysphagia. Br Dent J 180(12):465-466. https://doi.org/10.1038/sj.bdj.4809128

3. Bhatia S, Bounds G (1998) A broken needle in the pterygomandibular space: report of a case and review of the literature. Dent Update 25(1):35-37 
4. Zeltser R, Cohen C, Casap N (2002) The implications of a broken needle in the pterygomandibular space: clinical guidelines for prevention and retrieval. Pediatr Dent 24(2):153-156

5. Thompson M, Wright S, Cheng LH, Starr D (2003) Locating broken dental needles. Int J Oral Maxillofac Surg 32(6):642-644. https://doi.org/10.1054/ ijom.2003.0430

6. Ethunandan M, Tran AL, Anand R, Bowden J, Seal MT, Brennan PA (2007) Needle breakage following inferior alveolar nerve block: implications and management. Br Dent J 202(7):395-397. https://doi.org/10.1038/bdj.2007.272

7. Dojcinovic I, Hugentobler M, Richter M (2007) Needle breakage: a rare and potentially dangerous complication during local anesthesia. [French]. Rev Stomatol Chir Maxillofac 108(3):222-224. https://doi.org/10.1016/j.stomax.2 006.10 .005

8. Nezafati S, Shahi S (2008) Removal of broken dental needle using mobile digital C-arm. J Oral Sci 50(3):351-353. https://doi.org/10.2334/josnusd.50.351

9. Pogrel MA (2009) Broken local anesthetic needles: a case series of 16 patients, with recommendations. J Am Dent Assoc 140(12):1517-1522. https://doi.org/10.14219/jada.archive.2009.0103

10. Chrcanovic BR, Menezes DC Jr, Custódio ALN (2009) Complication of local dental anesthesia - a broken needle in the pterygomandibular space. Braz J Oral Sci 8:159-162

11. Augello M, von Jackowski J, Dannemann C (2009) Nadelbruch als Komplikation bei der intraoralen Leitungsanästhesie im Unterkiefer: [German]. Quintessenz 60:1263-1267

12. Hassani A, Motamedi M, Sadrimanesh R, Varshosaz M, Moshiri R, Vahdati SA, Sadr-Eshkevari P (2010) Use of cone beam computed tomography to detect and remove a broken suture needle. Gen Dent 58(6):534-536

13. Sencimen M, Bayar GR, Gulses A (2010) Removal of the retained suture needle under C-arm fluoroscopy: a technical note. Dent Traumatol 26(6): 527-529. https://doi.org/10.1111/j.1600-9657.2010.00939.x

14. Prado FB, Caria PFH, Martins EC, Daruge E (2010) Dental broken needle migration to the skull base, anatomical considerations and prevention. J Morphol Sci 27:98-101

15. Rifkind JB (2011) Management of a broken needle in the pterygomandibular space following a Vazirani-Akinosi block: case report. J Can Dent Assoc 77:b64

16. Bacci C, Mariuzzi ML, Ghirotto C, Fusetti S (2012) Local anesthesia needle breakage in a 5-year-old child during inferior alveolar nerve block with the Vazirani-Akinosi technique. [English, Italian]. Minerva Stomatol 61(7-8):337-340

17. Brucoli M, Deandreis M, Arcuri F, Benech A (2012) Management of a needle breakage during third molar extraction with C-ARM digital fluoroscope. Craniofac Surg 23(5):1583-1584. https://doi.org/10.1097/SCS.0b013e3182 505527

18. Catelani C, Valente A, Rossi A, Bertolai R (2013) Broken anesthetic needle in the pterygomandibular space, four case reports. [English, Italian]. Minerva Stomatol 62(11-12):455-463

19. Gerbino G, Zavattero E, BerroneM BS (2013) Management of needle breakage using intraoperative navigation following inferior alveolar nerve block. J Oral Maxillofac Surg 71(11):1819-1824. https://doi.org/10.1016/j. joms.2013.07.023

20. Kim JH, Moon SY (2013) Removal of a broken needle using threedimensional computed tomography: a case report. J Korean Assoc Oral Maxillofac Surg 39(5):251-253. https://doi.org/10.5125/jkaoms.2013.39.5.251

21. Nicot R, Maes JM, Raoul G, Ferri J (2013) Head and neck cellulitis caused by a broken anesthesia needle. [French]. Rev Stomatol Chir Maxillofac Chir Orale 114:180-183. https://doi.org/10.1016/j.revsto.2013.02.002

22. Rahman N, Clarke M, Stassen LF (2013) Case report: management of broken dental needles in practice. J Ir Dent Assoc 59(5):241-245

23. Ribeiro L, Ramalho S, Gerós S, Ferreira EC, Faria e Almeida A, Condé A (2014) Needle in the external auditory canal: an unusual complication of inferior alveolar nerve block. Oral Surg Oral Med Oral Pathol Oral Radiol 117: e436-e437. https://doi.org/10.1016/j.0000.2013.09.014, 6

24. Acham S, Reinbacher KE (2014) Nadelbruch im Rahmen der zahnärztlichen Lokalanästhesie. [German]. Quintessenz 65:1385-1393

25. Bailey E, Rao J, Saksena A (2015) A case report: fractured needle in the pterygomandibular space following administration of an inferior dental nerve block. Dent Update 42(3):270-272. https://doi.org/10.12968/denu.201 5.42.3.270

26. Casey JT, Lupo JE, Jenkins HA (2015) Retained dental needle migration across the skull base to the cochlea presenting as hearing loss. Otol Neurotol 36(2):e42-e45. https://doi.org/10.1097/MAO.0000000000000690
27. Lee TY, Zaid WS (2015) Broken dental needle retrieval using a surgical navigation system: a case report and literature review. Oral Surg Oral Med Oral Pathol Oral Radiol 119(2):e55-e59. https://doi.org/10.1016/j.00oo.2014. 08.019

28. Okumura Y, Hidaka H, Seiji K, Nomura K, Takata Y, Suzuki T, Katori Y (2015) Unique migration of a dental needle into the parapharyngeal space: successful removal by an intraoral approach and simulation for tracking visibility in X-ray fluoroscopy. Ann Otol Rhinol Laryngol 124(2):162-167. https://doi.org/10.1177/0003489414547106

29. Stein KM (2015) Use of intraoperative navigation for minimally invasive retrieval of a broken dental needle. J Oral Maxillofac Surg 73(10):1911-1916. https://doi.org/10.1016/j.joms.2015.04.033

30. Aktop S, Gocmen G, Ozturk ME, Gonul O, Varol A (2015) A rare case of a lost suture needle during third molar surgery. Case Rep Dent 2015:372153372153. https://doi.org/10.1155/2015/372153

31. Queiroz SB, Lima VN, Amorim PH, Magro-Filho O, Amorim RF (2016) Retrieval of a broken dental needle close to the facial artery after cervical migration. J Craniofac Surg 27(4):e338-e340. https://doi.org/10.1097/SCS. 0000000000002507

32. Blum T (1928) A report of 100 cases of hypodermic needles broken during the administration of oral local anaesthesia. Dent Cosmos 70:865-874

33. Augello M, von Jackowski J, Grätz KW, Jacobsen C (2011) Needle breakage during local anesthesia in the oral cavity - a retrospective of the last 50 years with guidelines for treatment and prevention. Clin Oral Investig 15(1): 3-8. https://doi.org/10.1007/s00784-010-0442-6

34. Archer WH, Mangie AS, Irby WB (1952) Removal of a broken mandibular needle using a modified Kazanjian guide; report of a case. Oral Surg Oral Med Oral Pathol 5(6):609-614. https://doi.org/10.1016/0030-4220(52)90247-8

35. Kennett S, Curran JB, Jenkins GR (1973) Management of a broken hypodermic needle: report of a case. Anesth Prog 20(2):48-50

36. Bedrock RD, Skigen A, Dolwick MF (1999) Retrieval of a broken needle in the pterygomandibular space. J Am Dent Assoc 130(5):685-687. https://doi. org/10.14219/jada.archive.1999.0278

37. Shah A, Mehta N, Von Arx DP (2009) Fracture of a dental needle during administration of an inferior alveolar nerve block. Dent Update 36(20-22): 25-687. https://doi.org/10.12968/denu.2009.36.1.20

38. Pietruszka JF, Hoffman D, Mcgivern BE Jr (1986) A broken dental needle and its surgical removal: a case report. N Y State Dent J 52(7):28-31

39. Cohen $R$ (1963) The removal of an imbedded broken suture needle by a simple magnet. J Pediatr 63(1):164-165. https://doi.org/10.1016/S0022-34 76(63)80316-9

40. Park SS, Yang HJ, Hwang SJ (2010) Removal of broken instruments in soft tissue at mandibular area using a dental mini C-arm. J Korean Assoc Oral Maxillofac Surg 32:567-572

\section{Publisher's Note}

Springer Nature remains neutral with regard to jurisdictional claims in published maps and institutional affiliations.

\section{Submit your manuscript to a SpringerOpen ${ }^{\circ}$ journal and benefit from:}

- Convenient online submission

- Rigorous peer review

- Open access: articles freely available online

- High visibility within the field

- Retaining the copyright to your article

Submit your next manuscript at $>$ springeropen.com 